\title{
Dietary non-digestible carbohydrates promote L-cell differentiation in the proximal colon of rats
}

\author{
Patrice D. Cani ${ }^{1}$, Sophie Hoste ${ }^{1}$, Yves Guiot ${ }^{2}$ and Nathalie M. Delzenne ${ }^{1 *}$ \\ ${ }^{1}$ Unit of Pharmacokinetics, Metabolism, Nutrition and Toxicology, PMNT 73/69, Université catholique de Louvain, Av. E. Mounier, \\ 1200 Brussels, Belgium \\ ${ }^{2}$ Department of Pathology, Cliniques Universitaires St Luc, Avenue Hippocrate, 10 (box 1712), B-1200, Brussels, Belgium
}

(Received 28 August 2006 - Revised 29 November 2006 - Accepted 4 January 2007)

\begin{abstract}
One of the challenges in type 2 diabetes treatment is to ensure pancreas functionality with gut peptides such as glucagon-like peptide-1 (GLP-1). We have recently shown that the endogenous GLP-1 production is promoted by dietary non-digestible carbohydrates (oligofructose), the higher GLP-1 secretion could participate in the control of obesity and associated disorders. This experimental study was designed to highlight the mechanisms of endogenous increase of GLP-1 following non-digestible carbohydrate feeding. Male Wistar rats were fed a standard diet (70.4 g/100 g total carbohydrates; controls) or the same diet supplemented with oligofructose ( $10 \mathrm{~g} / 100 \mathrm{~g}$ diet) for 4 weeks. GLP-1-producing L-cells of the colon were quantified by immunohistochemistry. GLP-1 was quantified by ELISA, and proglucagon, neurogenin 3 and NeuroD mRNA were measured in the colon by quantitative RT-PCR. The number of GLP-1-expressing cells was doubled in the proximal colon of oligofructose-treated rats, a phenomenon correlated with the increase in proglucagon mRNA and peptide content in the tissue. Moreover, oligofructose increased the number of enteroendocrine L-cells in the proximal colon by a mechanism involving up-regulation of two differentiation factors: neurogenin 3 and NeuroD. It is the first demonstration that nutrients fermented in the gut may promote L-cell differentiation in the proximal colon, a phenomenon contributing to a higher endogenous GLP-1 production. These results suggest a new mechanism by which dietary fibres may lower food intake and fat mass development.
\end{abstract}

L-cells: Neurogenin 3: NeuroD: Proglucagon: Carbohydrates

The regulation of energy homeostasis requires a specific detection of nutrients by specialized cells of the enteric area when absorbed by the digestive tract. The first actor of energy sensing is the intestinal epithelium where numerous endocrine cells are located. L-cells are the second most abundant population of endocrine cells in the human intestine, exceeded only by the population of enterochromaffin cells. A high abundance of L-cells is present in the colon (Moody, 1980; Bryant et al. 1983; Sjolund et al. 1983; Eissele et al. 1992). L-cells from the intestine are thought to arise from pluripotent stem cells in the crypts that also give rise to enterocytes, goblet cells and Paneth cells (Fujita et al. 2004). Stem cells located in the crypts differentiate into the four cell types present in the epithelium. Notch proteins mediate cell fate decisions and patterning by regulating expression of basichelix-loop-helix (bHLH) transcription factors that control terminal differentiation (Schonhoff et al. 2004). The sequential appearance of Math1, neurogenin 3 (NGN3) and BETA2/NeuroD (NeuroD) may represent distinct stages in the differentiation of enteroendocrine cells. NGN3 and NeuroD specifically drive cells into enteroendocrine cell types such as L-cells. The nature of positional cues that direct the distribution of each cell type has not been characterized yet (Fujita et al. 2004).

Glucagon-like peptide-1 (GLP-1) is a key hormone released from enteroendocrine L-cells in response to nutrient ingestion (Orskov et al. 1986). GLP-1 is produced by a tissue-specific post-translational processing of its precursor proglucagon peptide by prohormone convertase 1 enzymes (Dhanvantari et al. 1996). It promotes insulin secretion and $\beta$-cell proliferation in the pancreas, controls glycogen synthesis in muscle cells and promotes satiety (Brubaker \& Drucker, 2004; Holst, 2004; Knauf et al. 2005). These actions render GLP-1 highly attractive as a therapeutic agent, but a rapid enzymatic degradation of the molecule by dipeptidyl peptidase IV makes it unsuitable for injection (Deacon et al. 1998; Meier et al. 2004). Therefore, two pharmacological strategies are being pursued: the development of dipeptidyl peptidase IV-resistant analogues of GLP-1 and the development of dipeptidyl peptidase IV inhibitors. A way to promote endogenous GLP-1 secretion or stability would be useful in that context.

We and others have shown that non-digestible carbohydrates which are largely fermented in the colon, such as oligofructose (OFS), when added in the diet, improve glucose

\footnotetext{
Abbreviations: GLP-1, glucagon-like peptide-1; NGN3, neurogenin 3; OFS, oligofructose.

* Corresponding author: Prof. Nathalie M. Delzenne, fax + 32276473 59, email delzenne@pmnt.ucl.ac.be
} 
tolerance, insulin secretion and lower food intake in animals and in man. These effects are often associated with a higher plasma GLP-1 content (Yamashita et al. 1984; Piche et al. 2003; Cani et al. 2004, 2005a,b, 2006a). We have recently shown that the effects of OFS were abolished when it was given in the diet of GLP-1 Receptor knock-out mice, as well as in mice chronically treated with GLP-1 Receptor antagonist (exendin 9-39; Cani et al. 2006b). The mechanisms underlying the relation between non-digestible carbohydrate ingestion and GLP-1 production remain unknown. Some authors have proposed that the fermentation of non-digestible carbohydrate into SCFA allows those metabolites to promote proglucagon expression in intestine cells (Reimer \& McBurney, 1996; Reimer et al. 1997; Massimino et al. 1998). In the present study, we test the hypothesis that non-digestible carbohydrate could also target the enteroendocrine L-cell differentiation pathway.

\section{Materials and methods}

\section{Animals and diets}

Male Wistar rats (ten rats per group) weighing $145-160 \mathrm{~g}$ (Harlan, Horst, The Netherlands) were housed in individual cages in a temperature- and humidity-controlled room with a $12 \mathrm{~h}$ light-dark cycle. After an acclimation period of $5 \mathrm{~d}$ before the experiment, control rats were fed a powdered A04 standard diet (A04; UAR, Villemoisson-sur-Orge, France), whereas OFS-treated rats received a diet prepared by mixing $90 \mathrm{~g}$ A04 standard diet with $10 \mathrm{~g}$ corresponding fructan: Raftilose $\mathrm{P}_{95}$ (Orafti, Tienen, Belgium; Cani et al. 2004). The A04 standard diet contained the following (g/ $100 \mathrm{~g}$ dry diet): 19.3 protein (consisting of equivalent mix of soya and fish proteins); 70.4 total carbohydrates obtained from maize, wheat, barley and bran (including 38 starch, 3 saccharose, 5 cellulose and 8 non-digestible carbohydrates); 3 lipids; 6 mineral mixture and 1.3 vitamins. Food intake, taking into account spillover, was assessed three times per week. The mean daily energy intake $(\mathrm{kJ} / \mathrm{d})$ was calculated as follows: food intake $(\mathrm{g}) \times$ energy value of diet $(\mathrm{kJ} / \mathrm{g})$. The energy value for the control diet was $13.86 \mathrm{~kJ} / \mathrm{g}$ and for the OFS diet it was $13.08 \mathrm{~kJ} / \mathrm{g}$.

Rats were killed after 4 weeks of treatment. All experiments were approved by the local committee and the housing conditions were as specified by the Belgian Law of 14 November 1993 on the protection of laboratory animals (agreement no. LA 1230314).

\section{Chemicals}

Raftilose $\mathrm{P}_{95}$ is a mixture of glucosyl-(fructosyl) ${ }_{n}$-fructose and (fructosyl) $m$-fructose but with an average degree of polymerisation of 4.5 . Other chemicals used in the present study, of the purest grade available, were purchased from Sigma (St Louis, MO, USA) and Merck (Darmstadt, Germany).

\section{Blood samples}

On day 28 , food was withheld and $8 \mathrm{~h}$ later rats were anaesthetized by intraperitoneal injection of sodium pentobarbital solution (using $60 \mathrm{mg} \mathrm{Nembutal}{ }^{\circledR} / \mathrm{kg}$ body weight; Sanofi Santé
Animale Benelux, Brussels, Belgium). Portal vein blood samples were collected in EDTA tubes (Sarstedt, Nümbrecht, Germany) containing dipeptidyl peptidase IV inhibitor (Linco Research, St Charles, MO, USA); after centrifugation, plasma was stored at $-80^{\circ} \mathrm{C}$. GLP-1 $(7-36)$ amide was measured using an ELISA Kit, specific for GLP-1 (7-36) amide without cross-reactivity towards GLP-1 (9-36) amide, glucagon-like peptide-2 and glucagon (GLP-1 Active ELISA Kit; Linco Research).

\section{Tissue samples}

Colon was immediately excised, flushed with ice-cold saline buffer and divided into $2 \mathrm{~cm}$ segments taken just after the caecal junction, in the middle of the colon and just before the rectum, corresponding to proximal, medial and distal colon, respectively. Segments were immersed in liquid nitrogen, and stored at $-80^{\circ} \mathrm{C}$, for further analysis, or fixed overnight in $4 \%$ formaldehyde in PBS and routinely paraffinembedded. Full and empty caecum, and adipose tissues (epidydimal, inguinal, visceral and brow adipose tissue), were weighed.

\section{Intestinal peptide extractions}

Extraction of GLP-1 (7-36) amide from intestinal segments (caecum and colon) was carried out with ethanol-acid (100\% ethanol-sterile water-12 $\mathrm{M}-\mathrm{HCl}, 74: 25: 1)$ solution using $5 \mathrm{ml} / \mathrm{g}$ tissue. Samples were homogenized at $24000 \mathrm{rpm}$ and placed for $24 \mathrm{~h}$ at $4^{\circ} \mathrm{C}$. Homogenates were centrifuged (20 min at $2000 \mathrm{~g}$ ), and supernatant was decanted and diluted 200- and 500-fold in saline for caecum and colon, respectively. Concentrations of intestinal GLP-1 (7-36) amide were measured as previously described for blood samples.

\section{Quantitative $R T-P C R$}

Total RNA was isolated from intestine with TriPure Isolation Reagent (Roche, Basel, Switzerland) and single-strand cDNA was synthesized from $1 \mu \mathrm{g}$ total RNA by using oligo dT (Reverse Transcription Kit; Promega, Madison, WI, USA). Quantitative PCR was carried out with first-strand cDNA with primers for proglucagon sense, $5^{\prime}$-gtaatgctggtacaaggcag- $3^{\prime}$ and $5^{\prime}$-ttgatgaagtctctggtggca- $3^{\prime}$; for NGN3 sense, $5^{\prime}$ - aagagcgagttggcactgagc- $3^{\prime}$; antisense, $5^{\prime}$-aagctgtggtccgctatgcg- $3^{\prime}$; for NeuroD sense, $5^{\prime}$-cttggccaagaactacatctgg- $3^{\prime}$; antisense, $5^{\prime}$-cgtgtttgaaagagaagttgcc-3'; and as internal control RPL-19 sense, $5^{\prime}$-gaaggtcaaagggaatgtgttca- $3^{\prime}$; antisense, $5^{\prime}$-ccttgtctgccttcagcttgt- $3^{\prime}$ on an ABI Prism 5700HT sequence detection system, with SYBR green reagents (Applied Biosystems, Foster City, CA, USA), the threshold cycles $(\mathrm{Ct})$ were measured in separate tubes and in duplicate, and data were analysed according to the $2^{-\Delta \mathrm{Ct}}$ method. The identity and purity of the amplified product was checked through the analysis of the melting curve carried out at the end of amplification.

\section{Immunohistology}

Paraffin sections ( $3 \mu \mathrm{m}$ thickness) of proximal colon were immunostained by a rabbit anti-GLP-1 antibody (GLP-1 
antibody is directed against the N-terminal part of the GLP-1, leading to the detection of active form of GLP-1 (7-36 amide and $7-37) ; 1: 4000$, overnight incubation at $4^{\circ} \mathrm{C}$; Phoenix Pharmaceuticals, Mountain View, CA, USA) combined with a classical streptavidin-biotin-peroxidase detection system. Finally, the peroxidase activity was revealed by immersion in a solution of 3,3'-diaminobenzidine hydrochloride (0.05\% 3,3'-diaminobenzidine, brown deposit; Fluka, Buchs, Switzerland). Sections were counter-stained by Hemalun of Mayer (10 s), dehydrated and coverslipped with DPX mounting medium.

The number of immunopositive cells in the intestinal segments was counted in two non-serial immunostained sections, using a light microscope (final magnification $200 \times$ ), by an investigator blind to the experimental group. On the same material, mucosa area was manually delineated by the investigator and measured by a semiautomatic image analyser (Videoplan Kontron, Munich, Germany). Results are expressed as the number of L-cells per mucosal area (number $/ \mathrm{mm}^{2}$ ).

\section{Statistical analysis}

Results are expressed as means and their standard errors. Statistical differences between groups were evaluated by Student's $t$ test using GraphPad Prism version 4.00 for Windows (GraphPad Software, San Diego, CA, USA; www.graphpad.com). The level of significance was set at $P<0 \cdot 05$.

\section{Results}

Modulation of food intake, body weight and adiposity by oligofructose

Compared to the control diet, OFS feeding significantly reduced food intake, energy intake and body weight gain
(Fig. 1(A-D)). This was associated with lower epidydimal, inguinal and visceral adipose tissue, by about 30, 43 and $39 \%$, respectively. There was no effect on brown adipose tissue weight (Fig. 1(B)).

\section{Markers of fermentation}

Macroscopic analysis of the organs revealed caecum enlargement in OFS-fed rats. The total caecum weight was significantly higher in OFS-fed than in control rats (control, 4.37 (SEM0.32) g; OFS, 10.75 (SEM 0.8) g; $P<0.05$ ). The caecal tissue weight was significantly higher in OFS-fed than in control rats (control, 1.07 (SEM 0.06) g; OFS, 1.8 (SEM 0.06) g; $P<0 \cdot 05$ ).

\section{Modulation of glucagon-like peptide-1 production by oligofructose}

OFS feeding doubled portal GLP-1 plasma levels (Fig. 2(A)). We did not observe any modulation of proglucagon mRNA and GLP-1 content in the ileum, caecum and distal colon (data not shown). Therefore, we decided to focus on the proximal colon. Fig. 2 shows a similar increase (two-fold, versus control) of GLP-1 concentration and proglucagon mRNA in the proximal colon.

The number of GLP-1-positive L-cells in the proximal colon was also almost doubled following OFS treatment (Fig. 3(A)).

The histological analysis of colon segments showed no modifications of crypt height and numbers, and no sign of epithelial cell proliferation or apoptosis.

NGN3 is a key factor known to initiate endocrine differentiation; it activates the expression of BETA 2/NeuroD, which coordinates terminal differentiation (Fujita et al. 2004). (a)

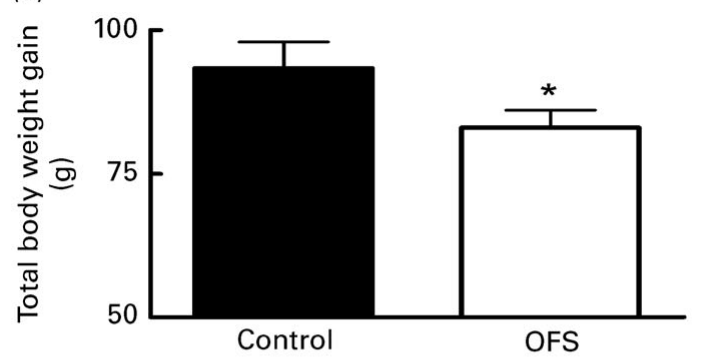

(c)

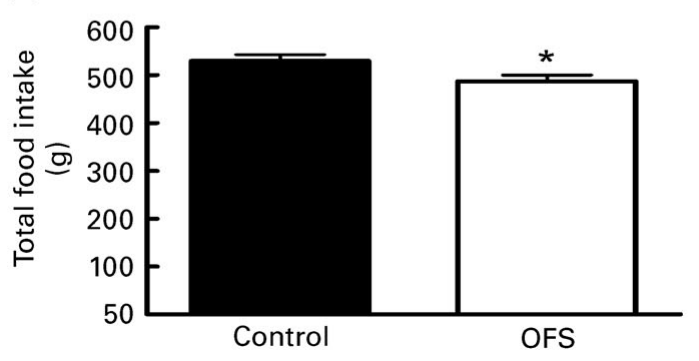

(b)

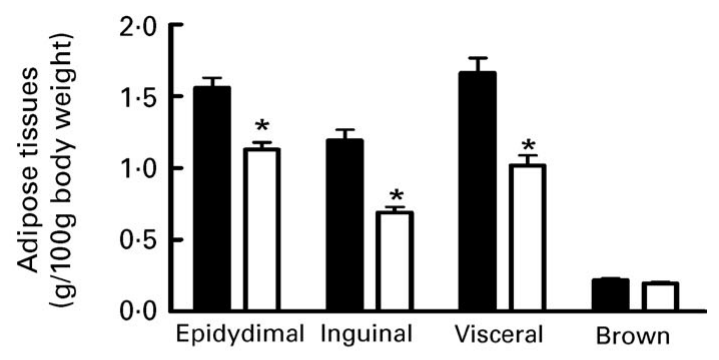

(d)

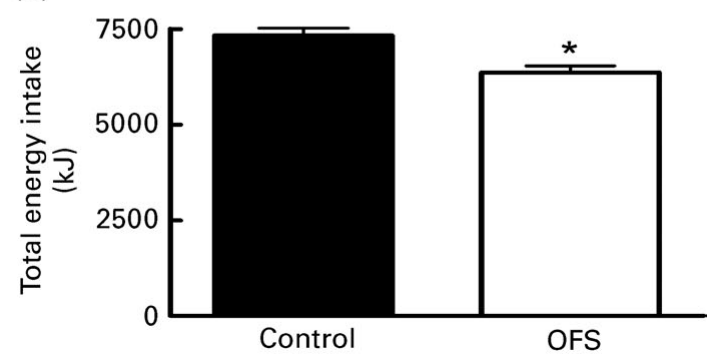

Fig. 1. The effect of oligofructose (OFS) on body weight gain (g) (A), adipose tissues ( $\mathrm{g} / 100 \mathrm{~g}$ body weight) (B), total food intake (g) (C) and cumulative energy intake $(k J)(D)$, of rats fed a control diet $(\square)$ or a diet supplemented with OFS $(\square)$.Values are means with their standard errors depicted by vertical bars $(n 10)$. Mean values were significantly different from those of the control group: * $P<0.05$. 

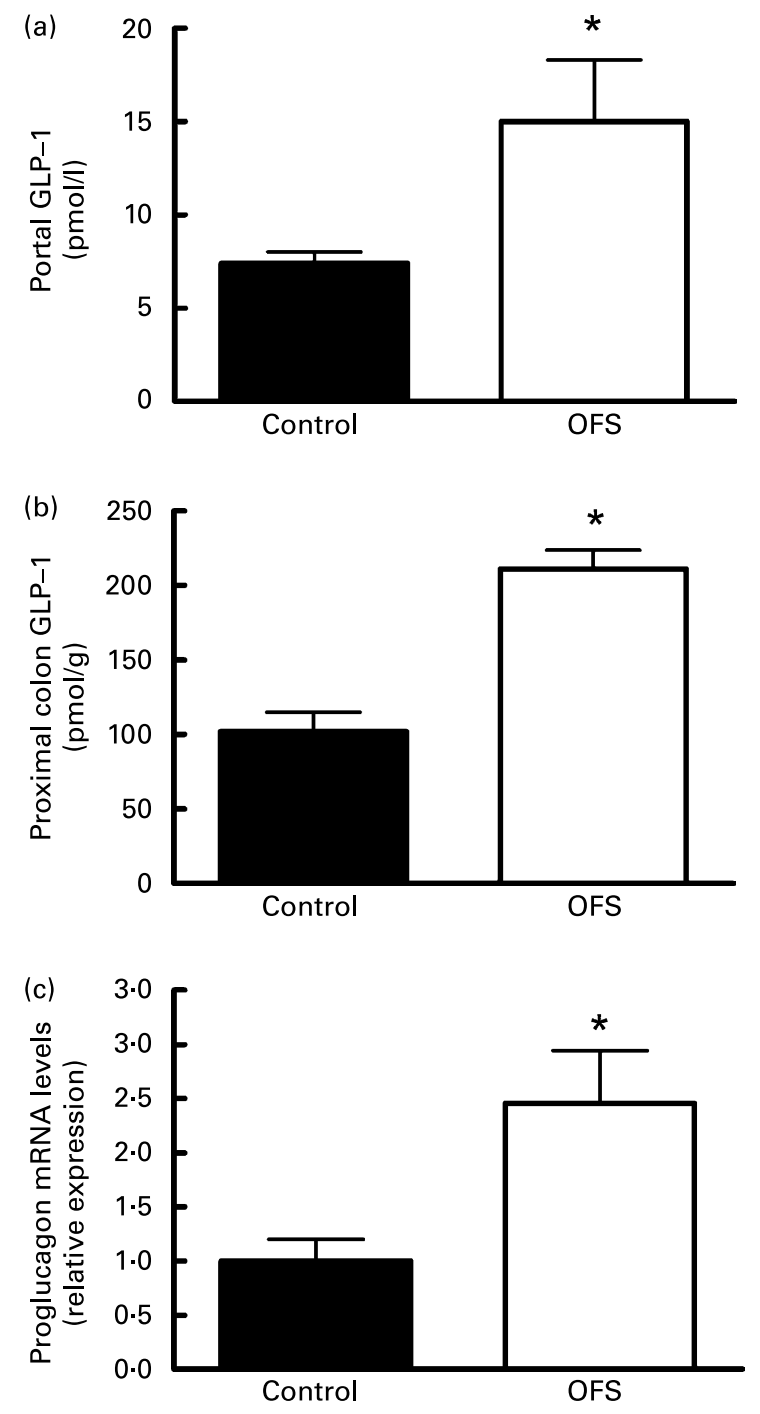

Fig. 2. The effect of oligofructose (OFS) on portal glucagon-like peptide-1 (GLP-1; 7-36) amide concentration (pmol/I) (A), proximal colon GLP-1 concentrations (pmol/g) (B) and proglucagon mRNA contents $(C)$ in the proximal

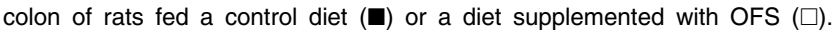
Values are means with their standard errors depicted by vertical bars $(n 10)$. Mean values were significantly different from those of the control group: ${ }^{*} P<0.05$.

We measured these two factors and found, in the proximal colon of OFS-fed animals, a significant increase of NGN3 and NeuroD expression, by about 2.7- and 1.4-fold, respectively (Fig. 3(B, C)). The present results suggest that OFS promotes the differentiation of cell precursors (stem cells) into mature L-cells, by the promoting expression of key differentiation factors.

\section{Discussion}

The present study confirms that non-digestible/fermentable carbohydrates, namely OFS, significantly increase proglucagon mRNA and GLP-1 peptide contents in the proximal colon without any modulation in the other intestinal segments (Cani et al. 2004, 2005a,b). OFS decreases food and energy intake, body weight gain and fat mass accumulation. This is
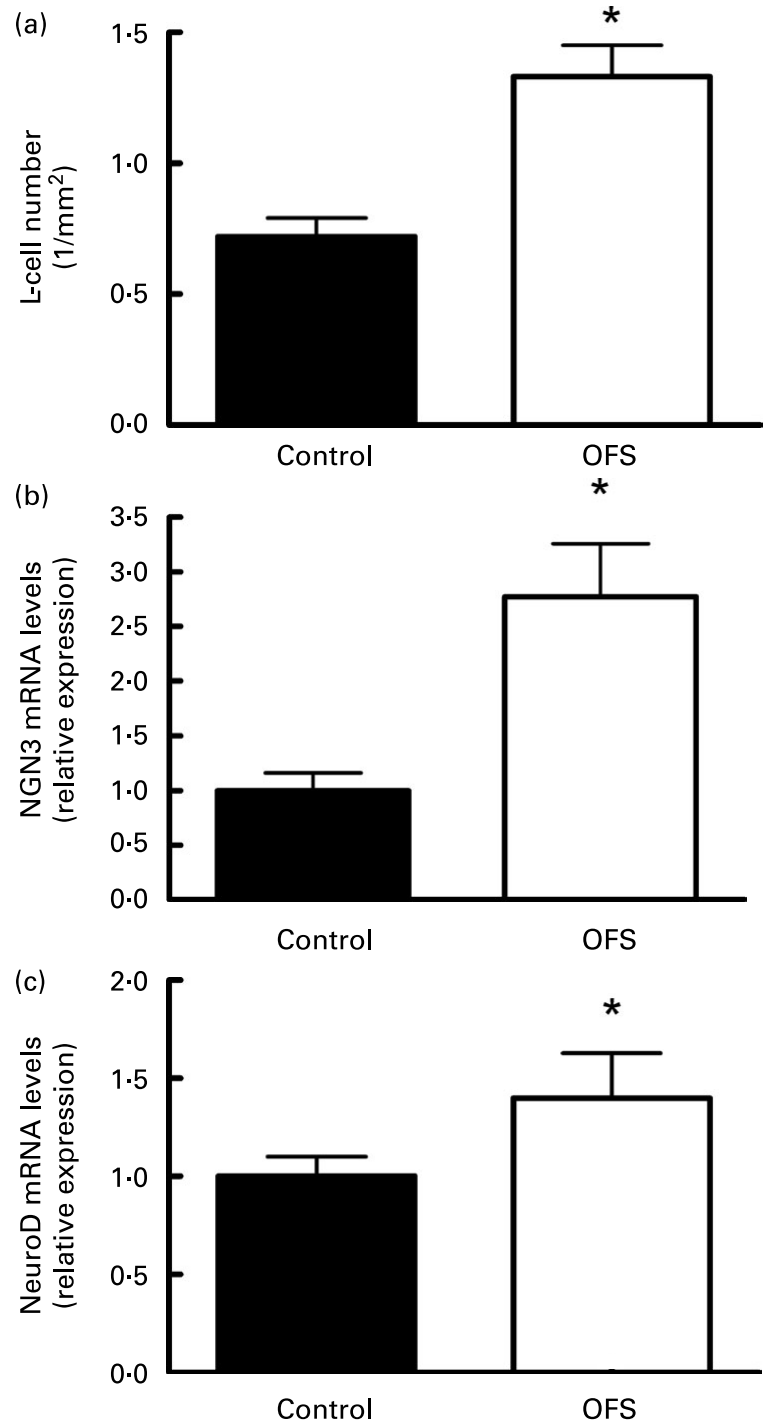

Fig. 3. The effect of oligofructose (OFS) on number of L-cells per $\mathrm{mm}^{2}(A)$, neurogenin 3 (NGN3) mRNA content (B) and NeuroD mRNA content (C) in the proximal colon of rats fed a control diet $(\square)$ or a diet supplemented with OFS ( $\square$ ). Values are means with their standard errors depicted by vertical bars $(n 10)$. Mean values were significantly different from those of the control group: ${ }^{*} P<0.05$.

associated with a significant increase of GLP-1 in the portal plasma vein and in the proximal colon tissue. We demonstrate for the first time that targeting the proximal colon by a nondigestible/fermentable compound promotes the endogenous GLP-1 content and that this effect is related to the increase in number of endocrine L-cells.

L-cells - as other intestinal cells - come from common stem cells. How stem cells are determined to differentiate into enteroendocrine cells is not completely understood. Controversies have been persisting for many years, questioning whether each endocrine cell type differentiates from its own precursor, or whether all enteroendocrine cells segregate from a common progenitor cell. The sequential appearance of Math1, NGN3 and NeuroD may represent distinct stages in the differentiation of enteroendocrine cells (Schonhoff et al. 2004). The nature of positional cues that direct the distribution of each cell type have not been characterized yet 
(Fujita et al. 2004). NGN3 is considered to be a pro-endocrine factor, since it is not identified in differentiated enteroendocrine cells, suggesting that this factor is transiently expressed and switched off prior to terminal differentiation (Schwitzgebel et al. 2000). A recent report demonstrates a direct relationship between the number of enteroendocrine cells and the expression of differentiation factors (Shroyer et al. 2005). Here, we observe that the doubling of the number of L-cells in the proximal colon upon OFS feeding is associated with a significant increase in NGN3 and NeuroD mRNA contents. The present results suggest a promotion of L-cell differentiation in the proximal colon by OFS. The only way to clearly show that NGN3 and NeuroD are key factors to explain the higher differentiation under OFS would be the use of specific tools to block those differentiation factors, the corresponding knock-out animals die post-natally (Gradwohl et al. 2000). The putative mechanism whereby OFS induce L-cell differentiation remains unknown. We may propose that OFS fermentation end-products such as SCFA (i.e. acetate, propionate and butyrate) are involved in such effects (Roberfroid \& Delzenne, 1998). Butyrate has been proposed as key regulator of intestinal cell differentiation in vitro, and appears as the best candidate to explain the putative modulation of colonic cell metabolism by modulating gene expression (Mariadason et al. 1997, 2000; Tappenden et al. 1998; Hodin, 2000). In fact, several studies have shown that butyrate is able to increase proglucagon gene expression in immortalised L-cells in vitro; the infusion of butyrate in the colon also increases proglucagon and GLP-1 contents (Dumoulin et al. 1995; Pratt et al. 1996). Moreover, the demonstration that the SCFA receptor GPR43 is expressed on L-cells puts forward that SCFA may be involved in the release of GLP-1 (Karaki et al. 2006). A previous study reports that in OFStreated rats, intestinal butyrate concentration is doubled (Le Blay et al. 1999). Moreover, the profile of SCFA - the relative proportion of acetate, propionate and butyrate - in the colonic content differs following the degree of polymerisation of non-digestible oligosaccharides ingested by rats (Nyman, 2002). The SCFA content is not similar in the caecal and colonic content of rats treated with OFS. The butyrate proportion was higher both in the caecum and proximal colon of OFS-fed animals than in control animals, while a higher butyrate level was found in the proximal colon than in the caecum. The butyrogenic properties of OFS have been recently confirmed (Nilsson \& Nyman, 2005).

Therefore, if butyrate is produced in a sufficient amount, it could contribute to increased GLP-1 production by both mechanisms: L-cell differentiation and/or increased proglucagon expression.

In conclusion, we confirm that non-digestible carbohydrates such as OFS increase endogenous GLP-1 production and portal plasma levels, a phenomenon contributing to control of body weight and adiposity. We demonstrate for the first time a relation between GLP-1 content, number of L-cells, NGN3 and NeuroD mRNA level in the colon: we thus propose that targeting the proximal colon with non-digestible dietary compound could increase L-cell differentiation by mechanisms linked to NGN3 and NeuroD up-regulation. The present results fit with the idea that events occurring in the colon (fermentation; modulation of gut microbiota) exert a key influence on the overall host metabolism (Backhed et al. 2004; Dumas et al. 2006). While the doses used in animal studies are not directly transposable to human nutrition, several reports suggest that the ingestion of fructo-oligosaccharides at the dose of $10-20 \mathrm{~g} / \mathrm{d}$ promotes physiological effects. A recent report demonstrates that OFS feeding (20 g/d) significantly increases plasma GLP-1 after a mixed meal (Piche et al. 2003). We have recently shown, in healthy human subjects, that feeding $16 \mathrm{~g} / \mathrm{d}$ OFS promotes satiety following breakfast and dinner, and reduces hunger and prospective food consumption after dinner. This was accompanied by a significant $10 \%$ lower total energy intake (Cani et al. 2006a). Moreover, Archer et al. (2004) have demonstrated that fermentable fructo-oligosaccharides, added to food as a fat replacer, were able to lower energy intake during a test day. The role of fermentable dietary fibres in the management of appetite in healthy human subjects has been recently confirmed (Whelan et al. 2006). It also gives a scientific rationale to promote the ingestion of fermentable dietary fibres - including oligosaccharides - to help control obesity and associated metabolic disorders.

\section{Acknowledgements}

P. D. C. is a Postdoctoral Researcher from the Fonds National pour la Recherche Scientifique (FNRS), Belgium. This work was supported by a FSR grant from the Université catholique de Louvain and FNRS grant 1.5.231.06. The authors thank Prof. I. Leclercq for providing access to q-PCR techniques and helpful criticisms. We also thank N. Maton for excellent technical assistance.

\section{References}

Archer BJ, Johnson SK, Devereux HM, Baxter AL (2004) Effect of fat replacement by inulin or lupin-kernel fibre on sausage patty acceptability, post-meal perceptions of satiety and food intake in men. Br J Nutr 91, 591-599.

Backhed F, Ding H, Wang T, Hooper LV, Koh GY, Nagy A, Semenkovich CF \& Gordon JI (2004) The gut microbiota as an environmental factor that regulates fat storage. Proc Natl Acad Sci U S A 101, 15718-15723.

Brubaker PL \& Drucker DJ (2004) Minireview: Glucagon-like peptides regulate cell proliferation and apoptosis in the pancreas, gut, and central nervous system. Endocrinology 145, 2653-2659.

Bryant MG, Bloom SR, Polak JM, Hobbs S, Domschke W, Domschke S, Mitznegg P, Ruppin H \& Demling L (1983) Measurement of gut hormonal peptides in biopsies from human stomach and proximal small intestine. Gut 24, 114-119.

Cani PD, Dewever C \& Delzenne NM (2004) Inulin-type fructans modulate gastrointestinal peptides involved in appetite regulation (glucagon-like peptide-1 and ghrelin) in rats. Br J Nutr 92, 521-526.

Cani PD, Daubioul CA, Reusens B, Remacle C, Catillon G \& Delzenne NM (2005a) Involvement of endogenous glucagon-like peptide-1(7-36) amide on glycaemia-lowering effect of oligofructose in streptozotocin-treated rats. J Endocrinol 185, 457-465.

Cani PD, Neyrinck AM, Maton N \& Delzenne NM (2005b) Oligofructose promotes satiety in rats fed a high-fat diet: involvement of glucagon-like Peptide-1. Obes Res 13, 1000-1007.

Cani PD, Joly E, Horsmans Y \& Delzenne NM (2006a) Oligofructose promotes satiety in healthy human: a pilot study. Eur J Clin Nutr 60, 567-572.

Cani PD, Knauf C, Iglesias MA, Drucker DJ, Delzenne NM \& Burcelin R (2006b) Improvement of glucose tolerance and hepatic insulin sensitivity by oligofructose requires a functional glucagonlike Peptide 1 receptor. Diabetes 55, 1484-1490. 
Deacon CF, Knudsen LB, Madsen K, Wiberg FC, Jacobsen O \& Holst JJ (1998) Dipeptidyl peptidase IV resistant analogues of glucagon-like peptide-1 which have extended metabolic stability and improved biological activity. Diabetologia 41, 271-278.

Dhanvantari S, Seidah NG \& Brubaker PL (1996) Role of prohormone convertases in the tissue-specific processing of proglucagon. Mol Endocrinol 10, 342-355.

Dumas ME, Barton RH, Toye A, et al. (2006) Metabolic profiling reveals a contribution of gut microbiota to fatty liver phenotype in insulin-resistant mice. Proc Natl Acad Sci USA 103, $12511-12516$.

Dumoulin V, Dakka T, Plaisancie P, Chayvialle JA \& Cuber JC (1995) Regulation of glucagon-like peptide-1-(7-36) amide, peptide YY, and neurotensin secretion by neurotransmitters and gut hormones in the isolated vascularly perfused rat ileum. Endocrinology 136, 5182-5188.

Eissele R, Goke R, Willemer S, Harthus HP, Vermeer H, Arnold R \& Goke B (1992) Glucagon-like peptide-1 cells in the gastrointestinal tract and pancreas of rat, pig and man. Eur J Clin Invest 22, 283-291.

Fujita Y, Cheung AT \& Kieffer TJ (2004) Harnessing the gut to treat diabetes. Pediatr Diabetes 5, Suppl. 2, 57-69.

Gradwohl G, Dierich A, LeMeur M \& Guillemot F (2000) Neurogenin 3 is required for the development of the four endocrine cell lineages of the pancreas. Proc Natl Acad Sci U S A 97, 1607-1611.

Hodin R (2000) Maintaining gut homeostasis: the butyrate-NFkappaB connection. Gastroenterology 118, 798-801.

Holst JJ (2004) On the physiology of GIP and GLP-1. Horm Metab Res 36, 747-754.

Karaki S, Mitsui R, Hayashi H, Kato I, Sugiya H, Iwanaga T, Furness JB \& Kuwahara A (2006) Short-chain fatty acid receptor, GPR43, is expressed by enteroendocrine cells and mucosal mast cells in rat intestine. Cell Tissue Res 324, 353-360.

Knauf C, Cani PD, Perrin C, et al. (2005) Brain glucagon-like peptide-1 increases insulin secretion and muscle insulin resistance to favor hepatic glycogen storage. J Clin Invest 115, 3554-3563.

Le Blay G, Michel C, Blottiere HM \& Cherbut C (1999) Prolonged intake of fructo-oligosaccharides induces a short-term elevation of lactic acid-producing bacteria and a persistent increase in cecal butyrate in rats. $J$ Nutr 129, 2231-2235.

Mariadason JM, Barkla DH \& Gibson PR (1997) Effect of short-chain fatty acids on paracellular permeability in Caco-2 intestinal epithelium model. Am J Physiol 272, G705-G712.

Mariadason JM, Rickard KL, Barkla DH, Augenlicht LH \& Gibson PR (2000) Divergent phenotypic patterns and commitment to apoptosis of Caco-2 cells during spontaneous and butyrate-induced differentiation. J Cell Physiol 183, 347-354.

Massimino SP, McBurney MI, Field CJ, Thomson AB, Keelan M, Hayek MG \& Sunvold GD (1998) Fermentable dietary fiber increases GLP-1 secretion and improves glucose homeostasis despite increased intestinal glucose transport capacity in healthy dogs. J Nutr 128, 1786-1793.

Meier JJ, Nauck MA, Kranz D, Holst JJ, Deacon CF, Gaeckler D, Schmidt WE \& Gallwitz B (2004) Secretion, degradation, and elimination of glucagon-like peptide 1 and gastric inhibitory polypeptide in patients with chronic renal insufficiency and healthy control subjects. Diabetes 53, 654-662.
Moody AJ (1980) Gut glucagon-like immunoreactants. Clin Gastroenterol 9, 699-709.

Nilsson U \& Nyman M (2005) Short-chain fatty acid formation in the hindgut of rats fed oligosaccharides varying in monomeric composition, degree of polymerisation and solubility. Br J Nutr 94, $705-713$.

Nyman M (2002) Fermentation and bulking capacity of indigestible carbohydrates: the case of inulin and oligofructose. Br J Nutr 87, S163-S168.

Orskov C, Holst JJ, Knuhtsen S, Baldissera FG, Poulsen SS \& Nielsen OV (1986) Glucagon-like peptides GLP-1 and GLP-2, predicted products of the glucagon gene, are secreted separately from pig small intestine but not pancreas. Endocrinology 119, 1467-1475.

Piche T, des Varannes SB, Sacher-Huvelin S, Holst JJ, Cuber JC \& Galmiche JP (2003) Colonic fermentation influences lower esophageal sphincter function in gastroesophageal reflux disease. Gastroenterology 124, 894-902.

Pratt VC, Tappenden KA, McBurney MI \& Field CJ (1996) Shortchain fatty acid-supplemented total parenteral nutrition improves nonspecific immunity after intestinal resection in rats. JPEN J Parenter Enteral Nutr 20, 264-271.

Reimer RA \& McBurney MI (1996) Dietary fiber modulates intestinal proglucagon messenger ribonucleic acid and postprandial secretion of glucagon-like peptide-1 and insulin in rats. Endocrinology 137, 3948-3956.

Reimer RA, Thomson AB, Rajotte RV, Basu TK, Ooraikul B \& McBurney MI (1997) A physiological level of rhubarb fiber increases proglucagon gene expression and modulates intestinal glucose uptake in rats. $J$ Nutr 127, 1923-1928.

Roberfroid MB \& Delzenne NM (1998) Dietary fructans. Annu Rev Nutr 18, 117-143.

Schonhoff SE, Giel-Moloney M \& Leiter AB (2004) Minireview: Development and differentiation of gut endocrine cells. Endocrinology 145, 2639-2644.

Schwitzgebel VM, Scheel DW, Conners JR, Kalamaras J, Lee JE, Anderson DJ, Sussel L, Johnson JD \& German MS (2000) Expression of neurogenin 3 reveals an islet cell precursor population in the pancreas. Development 127, 3533-3542.

Shroyer NF, Wallis D, Venken KJ, Bellen HJ \& Zoghbi HY (2005) Gfi1 functions downstream of Math1 to control intestinal secretory cell subtype allocation and differentiation. Genes Dev 19, 2412-2417.

Sjolund K, Sanden G, Hakanson R \& Sundler F (1983) Endocrine cells in human intestine: an immunocytochemical study. Gastroenterology 85, 1120-1130.

Tappenden KA, Drozdowski LA, Thomson AB \& McBurney MI (1998) Short-chain fatty acid-supplemented total parenteral nutrition alters intestinal structure, glucose transporter 2 (GLUT2) mRNA and protein, and proglucagon mRNA abundance in normal rats. Am J Clin Nutr 68, 118-125.

Whelan K, Efthymiou L, Judd PA, Preedy VR \& Taylor MA (2006) Appetite during consumption of enteral formula as a sole source of nutrition: the effect of supplementing pea-fibre and fructo-oligosaccharides. Br J Nutr 96, 350-356.

Yamashita K, Itakura M \& Kawai K (1984) Effects of fructo-oligosaccharides on blood glucose and serum lipids in diabetic subjects. Nutr Res 4, 961-966. 